\title{
PATRON-CLIENT SOCIAL RELATIONSHIP BETWEEN PALM OIL FARMERS AND OIL PALM MERCHANT IN KREUNG ITAM VILLAGE TADU RAYA DISTRICT NAGAN RAYA DISTRICT
}

\author{
Khori Suci Maifianti'); Dedy Darmansyah²); Ikhwanul Muslimin ${ }^{3)}$ \\ ${ }^{123)}$ Agribusiness Study Program Agriculture Faculty University of Teuku Umar \\ Email: ${ }^{1)}$ khorism@utu.ac.id ; ${ }^{2)}$ dedydarmansyah@utu.ac.id ; ${ }^{3)}$ \\ ikhwanmuslimin3@gmail.com
}

\begin{abstract}
How to Cite:
Maifianti, K., S., Darmansyah, D., Muslimin, I. 2021. Patron-Client Social Relationship Between Palm Oil Farmers and Oil Palm Merchant in Kreung Itam Village Tadu Raya District Nagan Raya District. Journal of Agri Socio-Economics and Business. 3 (1): 33-42. DOI: https://doi.org/10.31186/jaseb.3.1.33-42
\end{abstract}

\section{ARTICLE HISTORY \\ Received [18 May 2021] \\ Revised [31 May 2021] \\ Accepted [15 June 2021 \\ KEYWORDS \\ palm oil farmers, \\ Oil palm merchant, \\ patron-client, \\ social relationship,}

This is an open access article under the $C C-B Y-S A$ license

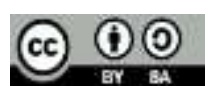

\section{ABSTRACT}

Krueng Itam village is one of the villages where the majority of the population works as oil palm farmers and depend their lives on oil palm plantations. In marketing to sell FFB (Fresh Fruit Bunch) palm oil farmers still rely on collector traders (agents) which in this case is referred to by the term "Oil palm merchant Sawit" (toke sawit). In the beginning, the relationship between palm oil farmers and the Oil palm merchant was limited to economic relations, such as the sale and purchase relationship between sellers and buyers. But in its developed, the relationship turns into a relationship of dependence and interest that leads to a patron-client relationship. This study used a descriptive qualitative method with data collection techniques through observation and interview process that is expected to be able to provide an overview of the social relationship between Oil palm merchant and farmers. Data analysis in this study uses four stages of data analysis (Miles and Huberman, 2007) where the stages are data reduction, data presentation, decision making and data verification. The total population in this study is 406 palm oil farmers, and 8 Oil palm merchants. The sample in this study is 5 member palm oil farmers from each toucan, so the number of informants Palm oil farmers used in this study are as many as 40 farmers. Based on the results of the study, the relationship between Oil palm merchant and palm oil farmers is a patron- client relationship where Oil palm merchant as the patron and palm oil farmers as clients. Palm oil farmers need Oil palm merchant to accomodate the harvest of palm oil FFB and Oil palm merchant needs palm oil FFB from farmers to be sold to Palm oil mills. In this cooperative relationship, farmers will usually borrow money for capital 
needs and others to the Oil palm merchant, this makes the farmers' dependence on the Oil palm merchant become greater so that each of them will maintain the relationship by respecting the existing norms so that the relationship has been established will not be broken easily. The relationship of patron-clients is more visible in the relationship between Oil palm merchant and small farmers, this is because there is a clear difference in socio-economic status between the two, so that the Oil palm merchant as a patron play a big role.

\section{INTRODUCTION}

Humans are social beings who impossibly live alone, this aims to provide mutual benefit. The important role of Oil palm merchant in the marketing of FFB as well as the provision of capital for palm oil farmers gives rise to dependence followed by striking differences in the ownership of economic resources. The patron-client relationship is vertical, this is because the Oil palm merchant is in a position of upper class status that has the power and strength, especially the strength of the resources it has. As noted by Levinson and Melvin Ember (1996) in Qurrata (2017), the patron-client relationship is seen as a socio-cultural fact and is based only on information agreements that are the link between political, social and economic relations colored by inequality, hence there is a big opportunity for the occurrence of exploitation.

The majority of the people of Kreung Itam Village make a living as palm oil farmers. In palm oil plantations with a pattern of self -management, intermediaries are needed in marketing FFB (Fresh Fruit Bunches) to consumers who in this case are Palm oil Mill, so that the profession of FFB agents or FFB collector traders, commonly called by the term palm Oil palm merchant or toke palm oil that buys and collects FFB harvested from farmers for resale to the mill so that this marketing task is done by the Oil palm merchant.

Looking at the background of the dependence relationship between palm oil farmers and Oil palm merchant in running a business and the various socio-economic aspects that go with it makes researchers interested in researching the "patron-client social relationship between palm oil farmers and Oil palm merchant in Kreung Itam village, Tadu Raya sub-district, Nagan district.

\section{RESEARCH METHODS}

\section{Method of Collecting Data}

This study was conducted on March 2, 2020 to June 27. The total population in this study is 406 palm oil farmers, and 8 Oil palm merchants. The sample in this study is 5 member palm oil farmers from each toucan, so the number of informants Palm oil farmers used in this study are as many as 40 farmers. Determination of informants of palm oil farmers is done by snowball sampling method that is the determination of the sample/informants that are initially small and then grow like a snowball (Sugiyono, 2012) 


\section{Data Analysis Method}

Data analysis is a way to process data from obtained sources in the research such as interviews, observations, field notes, personal documents, official documents, pictures, photographs, etc. are converted into information so that it is easy to understand and conclusions can be drawn (Suprapti, 2018). Data analysis in this study uses four stages of data analysis (Miles and Huberman, 2007) where the stages are data reduction, data presentation, decision making and data verification.

\section{RESULTS AND DISCUSSION}

\section{Overview of Research Sites}

Kreung Itam village is one of the villages in Tadu Raya District as palm oil production center which has an area of $1,702 \mathrm{Ha}$. Initially, Krung Itam Village was a transmigration community brought from the island of Java in 1981 through the Transmigration program held by the government. In the beginning, the main livelihood of the people at that time was food crop farmers, but due to failure, in 1989 it was changed to plantation crops with palm oil commodity until then.

\section{Characteristics Overview of Oil palm merchant Informants}

Table 1. Characteristics of Oil palm merchant Informants in Kreung Itam Village

\begin{tabular}{|c|c|c|c|}
\hline No & Information & person & Percentage (\%) \\
\hline \multirow[t]{4}{*}{1} & Sex & & \\
\hline & Male & 6 & 75 \\
\hline & Female & 2 & 25 \\
\hline & Total & 8 & 100 \\
\hline \multirow[t]{5}{*}{2} & Age (years) & & \\
\hline & $28-36$ & 1 & 12,5 \\
\hline & $37-45$ & 3 & 37,5 \\
\hline & $46-54$ & 4 & 50 \\
\hline & Total & 8 & 100 \\
\hline \multirow[t]{6}{*}{3.} & Education & & \\
\hline & Elementary & 4 & 50 \\
\hline & Junior High School & 0 & 0 \\
\hline & Senior High School & 2 & 25 \\
\hline & University Degree & 2 & 25 \\
\hline & Total & 8 & 100 \\
\hline \multirow[t]{5}{*}{4.} & Work Experience & & \\
\hline & $1-5$ & 3 & 37,5 \\
\hline & $6-10$ & 4 & 50 \\
\hline & $11-15$ & 1 & 12,5 \\
\hline & Total & 8 & 100 \\
\hline \multirow[t]{4}{*}{5.} & SPB Ownership & & \\
\hline & Yes & 3 & 37,5 \\
\hline & No & 5 & 62,5 \\
\hline & Total & 8 & 100 \\
\hline
\end{tabular}

Journal of Agri Socio-Econmic and Business, Vol. 03 No. 1 June 2021 page $33-42 \mid 33$ 


\begin{tabular}{llcc}
\hline 6. & & \\
& Number of Clients (farmers) & 6 & 75 \\
$13-48$ & 0 & 0 \\
$49-84$ & 2 & 25 \\
$85-120$ & 8 & 100 \\
Total & & \\
7. & 5 & 62,5 \\
& Type of Loan Given & 3 & 37,5 \\
Money & 3 & 100 \\
Money and Fertilizer & 8 & \\
Total & &
\end{tabular}

Source:Primary Data 2020 (processed)

Based on table 1, it can be explained that the palm Oil palm merchant profession in Kreung Itam Village is dominated by men. This proves that the level of male labor participation is always higher than the level of female labor participation because men are considered as the main breadwinner in the family. As found by payaman (2001) in setiawan (2010), almost all men who have reached working age are involved in economic activities because men are the main breadwinners in the family.

The task of the Oil palm merchant is only to give instructions to farmers and employees, take records, supervise employees and make payments or transactions to farmers on the FFB of the harvest they sell, so that it can be done by both men and women. It can be concluded that the status as a patron is not limited to men only.

Oil palm merchant in the village of Krueng Itam is dominated by Oil palm merchant with the age of $40-50$ years, this is because at that age a person has reached the challenge of thinking, acting, judgment, work ethic, commitment and good work experience.

The level of education of Oil palm merchant in Kreung Itam Village is only elementary education, this is due to the economic situation of his family which was less supportive and difficult to pursue education. Although only at the elementary level, in the past, to be able to finish elementary school was already a higher education. In this case the level of education of a patron will also strengthen his position in social status and be recognized as a patron.

Riyanti (2003) in kriswanto (2020), experience in doing a business is the best thing in the success of a business, the longer a person engages in the field of business, the more the person will understand and succeed if done well and correctly. Similar to the FFB (Fresh Fruit Bunch) trading business, FFB traders who have been doing FFB buying and selling business activities for a long time will have more power, both from the ability to interact with consumers and the number of customers they have and more experience in the world of FFB (Fresh Fruit Bunch) palm oil.

From the results of the research, it can be seen that most of the Oil palm merchant have had a long enough experience in running the FFB business, so it can be said that they are experienced enough. The long experience of the business is also the long experience of Oil palm merchant as a patron for its clients, this is related to the trust of farmers who become its clients is proven by the presence of loyal farmers who have subscribed to Oil palm merchant from the beginning of Oil palm merchant opened the business until now when the study was conducted. Such trust is built by the Oil palm merchant by maintaining good relations with its customer farmers and meeting the needs of farmers who need the help of the Oil palm merchant. 
FFB (Fresh Fruit Bunch) agreement letter is a form of letter used by both farmers and traders to be able to enter the Palm oil Mill as proof of selling FFB (Fresh Fruit Bunch). Letter of agreement or more often called SP among Oil palm merchant is the main condition to be able to sell FFB to Palm oil mills. Agreement Letter is issued by the Palm Oil Mill management to business entities that have established cooperative relationships as suppliers of FFB for the mill providing delivery letter. Based on the results of the research, not all Oil palm merchant in Krueng Itam Village have their own Agreement Letter, some of the Oil palm merchant borrow the Agreement Letter belonging to other Oil palm merchant.

In running their business and to keep their customers subscribed to the Oil palm merchant, it provides facilities in the form of loans with terms and payment mechanisms that are easy and not burdensome for farmers because the size of the payment could be adjusted according to the harvest yield and can be paid off during the subscription. There are two types of loans provided by the Oil palm merchant to their palm oil farmers, namely in the form of cash and fertilizer. Money Loan is more popular among the farmers, this is because farmers can easily allocate the money loaned for various needs ranging from buying fertilizers, farm land maintenance costs or daily necessities. Loans are an important thing that must be provided by the Oil palm merchant to farmers as a provider of the capital needs of oil palm farmers in running their farming business so that this causes farmers become dependent on the Oil palm merchant.

In the patron-client relationship, the loan provided by the Oil palm merchant is a form of assistance and protection for the guarantee of the availability of capital and economic needs for farmers when farmers are experiencing a crisis or when crop yields are declining. Loans are used by the Oil palm merchant to tie the relationship between the farmer and the Oil palm merchant and at the same time strengthen the Oil palm merchant's position as a patron in his relationship with the farmer as a client. Kausar and Zaman (2011) said that one way to strengthen the position of toke was to lend money to the farmers.

\section{Characteristics Overview of Palm Oil Farmer Informants}

Table 2. Characteristic of Palm Oil Farmer Informants

\begin{tabular}{llll}
\hline No & KInformation & Person & Percentage (\%) \\
\hline 1 & Sex & & \\
& Male & 37 & 92,5 \\
& Female & 3 & 7,5 \\
& Total & 40 & 100 \\
\hline 2 & Age (years) & & \\
& $23-33$ & 6 & 15 \\
& $34-44$ & 12 & 30 \\
& $45-55$ & 13 & 32,5 \\
& $56-66$ & 3 & 7,5 \\
& $67-77$ & 4 & 10 \\
& $78-88$ & 2 & 5 \\
& Total & 40 & 100 \\
\hline 3 & Education Level & & \\
& Elementary & 19 & 47,5 \\
& Junior High School & 6 & 15 \\
\hline
\end{tabular}

Journal of Agri Socio-Econmic and Business, Vol. 03 No. 1 June 2021 page 33 - 42| 33 


\begin{tabular}{llll}
\hline & Senior High School & 9 & 22,5 \\
University Degree & 2 & 5 \\
& Less than elementary & 4 & 10 \\
& Total & 40 & 100 \\
\hline $4 . \quad$ Experience & & \\
$4-12$ & 10 & 25 \\
$13-21$ & 13 & 32,5 \\
& $22-30$ & 17 & 42,5 \\
& Total & 40 & 100 \\
\hline $5 \quad$ Loan relationship to the Oil palm & \\
merchant & 27 & 67,5 \\
& Applicable & 13 & 32,5 \\
& N/A & \\
Total & 40 & \\
\hline
\end{tabular}

Iriyani and Nugrahani (2016), Gender is a category in society based on sex or gender (biological differences). Based on table 2, it can be seen that the oil palm farmer profession is dominated by men from the total. Indonesian oil palm farmers as well as farmers who work in other agricultural sectors are more dominated by men, where in eastern culture, men are still seen as the breadwinner of the family's economy and women only act as supporters (Darto, 2012).

The age of the farmer is one of the factors that is closely related to the ability to work in carrying out farming activities. As stated by Pratiwi and Pinem (2020), the older the farmer, the weaker the farmer's physical condition will be and vice versa if the farmer is still young, the farmer's physical ability will be greater to manage the farm. The explanation shows that the largest percentage of respondents are in the age range $34-44$, and $45-55$ years with a total percentage of $62.5 \%$ where that age range is still in the productive age range. Bakir and Manning (1984) say that the productive age for working in developing countries is generally $15-55$ years. At that productive age, a person has great potential to develop farming and increase the production and income.

Even though it is still at the lowest level, this condition shows that the farmer's level of literacy is good enough. Furthermore, if it is viewed from the explanation of the table above, it can be concluded that the farmers are not only able to read and write, but also sufficiently enough to absorb more detailed information in a written format.

Judging from the experiences of farmers in this study, the majority of respondents have been involved in farming for a long time and have sufficient experience in farming, this also illustrates that oil palm is the main agricultural commodity that is the priority of farmers and the main source of income for farmers.

From table 2 it can be seen that out of 40 respondents of palm oil farmers, 27 people $\left(67^{\prime} 5 \%\right)$ had a loan or debt relationship to the business owners at the time the research was conducted. As for the remaining 13 people (32.5\%) farmers do not have a loan / debt relationship to the business owner or have repaid the loan, even though they still sell their harvested FFB to the businessman with the intention of maintaining a relationship of cooperation and trust, so that at any time it is needed they can easily ask for a loan to the Oil palm merchant.

Social Interaction Between Oil Palm Farmers and Oil Palm Oil palm merchant

38 | Maifianti, K., S., Darmansyah, D., Muslimin, I. 2021. Patron-Client Social... 
Social interactions are social relationships involving relationships between individuals, individuals (a person) with groups, and groups with groups. Without social interaction, there would be no coexistence between these individuals (Herlina, 2014).

In conducting harvested FFB, oil palm farmers depend on the Oil palm merchant, this happens because farmers cannot sell FFB directly to the mill because they do not have economic resources, either transportation capital or access to directly selling FFB to the mill. In this case, it is in accordance with one of the characteristics of the patron client relationship stated by Scott, namely "There is an unbalanced ownership of economic resources" between oil palm farmers and oil palm traders.

An imbalance can be seen where oil palm farmers do not have access to sell FFB directly to the palm oil mill because to do this the main requirement is SPB (Fruit Introduction Letter), while the Oil palm merchant has all the resources and capital needed to access and market FFB to the mill such as SPB, loading vehicles and sales on a large scale. Apart from not having all the economic resources and another supporting capital, such as cars for transporting FFB and generally their production amounts are small.

The characteristics of this patron-client relationship can be seen clearly in the relationship between the Oil palm merchant and small farmers where the differences in social and economic status between the two are very clear. Oil palm merchant has an average income that is much higher than the farmer, this is because the oil palm Oil palm merchant, apart from being the Oil palm merchant, also has extensive oil palm plantations. The life of the Oil palm merchant tends to be more stable with the ownership of luxury items such as a larger house and private car, which in turn makes the Oil palm merchant's socioeconomic status higher among the community and farmers. This is very different from the socioeconomic status of small oil palm farmers who only have small oil palm plantations so that their income is also small, this makes the socioeconomic status of the farmers lower than the Oil palm merchant. With the resources owned, the Oil palm merchant as the patron will provide protection and guarantee of subsistence to the member palm oil farmers as clients. The protection provided is in the form of money loans, and protection from losses in the form of guarantees for the purchase of crops.

A good attitude in establishing a cooperative relationship with farmers and the loans provided by the Oil palm merchant makes farmers attached to the Oil palm merchant and this is seen as a service provision that must be repaid by the farmer as in the concept of an exchange relationship with the patron client.

The form of payback is in the form of loyalty or compliance from the client to the Oil palm merchant as the patron, this relationship is what Scott refers to as a "loyalty relationship". In this case the loyalty in question is an action from the farmers (clients) to the Oil palm merchant (patron) to repay the services or gifts they have received from the patron, this is also intended to balance the exchange relationship given to what is given by the Oil palm merchant to farmers. The loyalty of farmers to the Oil palm merchant can be seen that the farmers do not want to divert the FFB sales from their harvest to other Oil palm merchant, even though the price in other Oil palm merchant is higher.

\section{Factors Causing Patron Client Relationships Between Palm Oil Farmers and Oil palm merchant}

Journal of Agri Socio-Econmic and Business, Vol. 03 No. 1 June 2021 page $33-42 \mid 33$ 
Cooperation may occur when a person or group of people get the benefit from another person or group, and vice versa, both parties who hold social relations consider cooperation more beneficial than work alone (Abdulsyani, 2002). Based on the results of the study, the patron-client relationship that occurs between oil palm farmers and oil palm traders in Kreung Itam Village is based on a mutually beneficial relationship between farmers and business owners. In interacting, humans always consider sacrifices with rewards or benefits obtained from these interactions (Wibawa, 2015).

Table 3. Factors Causing Patron Client Relationships between Palm Oil Farmers and Oil palm merchant

No Patron Client Relationship Factors

1. $\quad$ Marketing Factors

Ownership of SPB (Agreement Letter)

Total Production

Price and Discounts (Percent)

Guarantee of FFB Purchase

$2 . \quad$ Facilities for transport and FFB Loading

3. $\quad$ Trust

4. $\quad$ Norms and Values

The Loan from the boss is the reason for the farmer subscribes to the Oil palm merchant, when the big need that must be met by the farmer will borrow money to the Oil palm merchant. Sometimes the Oil palm merchant's willingness to provide loans is a determining factor whether farmers will continue to subscribe or move to other Oil palm merchant who can provide loans and according to their requests.

From the results of the research conducted, the patron-client relationship that occurs between palm oil farmers and oil palm Oil palm merchant in Kreung Itam Village is a relationship that needs each other, both the Oil palm merchant and the farmers play their roles both in the sale-purchase and social cooperation relationship so that there is no exploitation actions carried out by the Oil palm merchant as a patron to farmers as clients and vice versa so that the theory of Levinson and Melvin Ember regarding exploitation in the patron-client relationship is not proven.

\section{CONCLUSIONS AND RECOMMENDATIONS}

\section{Conclusions}

The relationship between the Oil palm merchant and the farmer is a patron-client relationship where in this relationship the Oil palm merchant is the patron and the farmer as the client. This patron client relationship is stronger in the relationship between the Oil palm merchant and small farmers where there is a difference in status

40 | Maifianti, K., S., Darmansyah, D., Muslimin, I. 2021. Patron-Client Social... 
between the two and the role of the Oil palm merchant as a patron becomes more seen. The factors causing the patron-client relationship are marketing factors, capital factors, loan factors, trust factors, value factors and norms.

\section{Recommendations}

Oil palm merchant could strengthen its relationship with palm oil mills to assist farmers in increasing farmer income through educating farmers about the types and criteria of good quality FFB so that the purchase price of farmers' FFB is higher, this will make farmers more loyal to the Oil palm merchant.

\section{REFERENCES}

Miles M B, Huberman A. M. Qualitative Data Analysis. Tjetjep Rohendi Rohidi, translator. Jakarta (ID): University of Indonesia. Translation of Qualitative Data Analysis.

Qurrata, V. Annisa. 2017. Patron Client: Semi Mudharabah Contract In Agency Theory in Marine Fisheries. Journal of El Dinar.Vol 5. No.1.

Sugiyono. 2010. Research Method of Education Quantitative, Qualitative and $R$ $\& D$. Bandung Approach: Alphabet.

Suprapti, Desi. 2018. Client Patron in Palm Oil Farming. [thesis]. Medan (ID): University of North Sumatra.

Setiawan, Satrio Adi. 2010. The Influence of Age, Education, Income, Work Experience and Gender On Long-Term Employment for Educated Workers in Magelang City. [thesis]. Semarang (ID): Diponegoro University.

Kriswanto. 2020. Analysis of The Behavior and Market Performance of TBS (Bunches of Fresh Fruit) Palm Oil Plantation People in Darul Makmur Subdistrict Nagan Raya. [thesis]. Meulaboh (ID): Teuku Umar University.

Kausar dan Komar Zaman,. 2011. Analysis of Patron-Client Relations (Case Study of Toke Relationship And Smallholders Of Self-Help Pattern In North Tambusai Subdistrict of Rokan Hulu Regency). Indonesian Journal of Agricultural Economics (IJAE). Vol. 2 No. 2.

Iriyani, Dwi dan Pangesti Nugrahani,. 2016. Characterization of SocioEconomic Factors Based on Analysis of Principal Components in Periurban Agriculture, Surabaya. Journal of Engineering Vol 9 No 1, April 2016, pp. 18-41. Volume 9 Number 1.

Darto, Mansuetus. 2017. Characteristics of SmallHolder Farmers in the Context of Sustainable Palm Oil Profile: Bengkalis and Siak, Riau, Ketapang and Kubu Raya Districts, West Kalimantan, and North Konawe Regency, Southeast Sulawesi. USAID.

Pratiwi, Myrna dan L. Juita Pinem,. 2020. Characteristics of Oil Palm Farmers in Labuhan Batu Utara Regency. Agriprimatech Journal Vol. 3 No. 2, April 2020. 
Bakir, S. Z., \& Manning, C. 1984. Indonesian Labor Force: Participation, Opportunity and Unemployment. Published for Ugm Population Research Center. hawk.

Herlina. 2014. Social Interaction of Agricultural Extension As An Effort to Improve Farming of Farmers in Batang Regency. Journal of Education Social Studies. Vol. 3.

Abdulsyani. 1994. Sociology of Schematics, Theory and Applied. Pt.. Earth Script. Jakarta.

Wibawa, S. Prabawati dan Bambang S. 2015. Client Patron Working Relationship In Winong Tile Making Industry Center (Case Study between Employers and Workers of Tile Making Industry Center in Gulun Village, Maospati District, Magetan Regency, East Java Province). [thesis]. Surakarta (ID): Sebelas Maret University. 